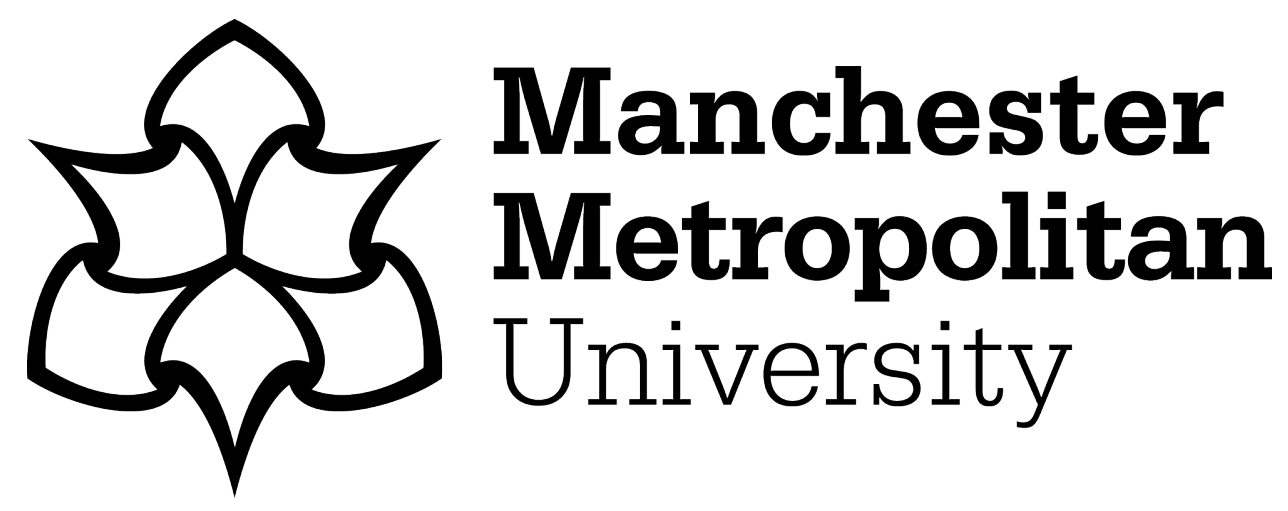

Grix, Jonathan and Kramareva, N (2017) The Sochi Winter Olympics and Russia's unique soft power strategy. Sport in Society, 20 (4). pp. 461-475. ISSN 1743-0437

Downloaded from: https://e-space.mmu.ac.uk/621301/

Version: Accepted Version

Publisher: Taylor \& Francis (Routledge)

DOI: https://doi.org/10.1080/17430437.2015.1100890

Please cite the published version 


\section{The Sochi Winter Olympics and Russia's Unique Soft Power Strategy}

\section{Jonathan Grix and Nina Kramareva,}

Sport, Exercise and Rehabilitation Sciences, University of Birmingham

\section{Corresponding author: J.Grix@bham.ac.uk}

According to Joseph Nye, who coined the concept of 'soft power', Putin 'failed to capitalize on the soft-power boost afforded to Russia by hosting the 2014 Winter Olympic Games in Sochi' (Nye, 2014). With political volatility in the region throughout the year, Russia's ensuing actions - culminating in the secession of Crimea - and its position over the armed conflict in Ukraine, certainly appear to bear this out. The Sochi Olympics were predominantly framed by the Western press as a Russian soft power quest and an attempt to obtain belated recognition as a great power. However, Sochi should be understood as a part of a wider package of "spatial governance" undertaken by Putin's regime. We argue that the Sochi mega-event is part of a wider soft power strategy - one which is not the same as, for example, the UK's or Brazil's use of such events. For Russia, international status means possessing both soft and hard power resources and being able to use them.

Key words: Soft power; Russia; Sports mega-events; Sochi Olympics; national identity.

\section{(ORIGINAL MANUSCRIPT)}

This is the Authors' Original Manuscript in its final and definitive form. The Version of Record can be found via the following reference:

Grix, J., \& Kramareva, N. (2015). The Sochi Winter Olympics and Russia's unique soft power strategy. Sport in Society, 1-15 available at:

\section{http://www.tandfonline.com/doi/abs/10.1080/17430437.2015.1100890}




\section{Introduction}

The intention in what follows is to outline how and why Russia's "soft power" strategy does not follow a similar trajectory to, nor is it the same as, other states who have drawn upon sports mega-events to showcase their nations. Commentators are quick to lump together BRIC countries as the new wave of mega-event hosts, yet the strategies adopted by each and the goals they seek to reach differ greatly (see Black, 2008; Baviskar, 2014; Horne and Manzenreiter, 2006). This is nowhere more evident than in the case of Russia. As this paper shows, the common denominators of status-seeking, externally-focused, image-improving strategies employed by the vast majority of sports mega-evens hosts cannot be simply extrapolated to Russia's case.

The paper proceeds as follows: first we he case of Russia. As this paper shows, the couture on soft power and sports mega-events before turning to the Western-centric "framing" of Russia's actions in particular in relation to the Sochi Winter Olympics in 2014. We then analyse the Kremlin's soft power agenda based on the official political discourse and the messages transmitted in the run-up and throughout the course of the Olympic Games. The next section puts forward the idea that the hosting of the Sochi Games and the annexation of Crimea were mutually reinforcing events towards laying the foundations of an emergent new viable national identity, rather than claims for Russia's "great power" status. We suggest, therefore, that the Russian soft power project targets primarily a domestic audience, which represents a stark contrast to the soft power agenda of developed and other "emerging" nations and previous sports mega-events hosts. Finally, we sketch out the contours of Russia's soft power strategy in view of the repercussions of the Ukrainian conflict.

\section{Mega-events: theoretical approach}

Interestingly, the study of the political use of sport and sports mega-events has, paradoxically perhaps, not been carried out in the main by political scientists and international relations scholars, but rather by sociologists, historians and 'sports studies' scholars alike (Giulianotti, 2015; Persson and Petersson, 2014; Muller, 2014; Almeida et al, 2013). While this is changing slowly, key concepts deriving from the former academic disciplines are making their way into sports studies. One such concept, "soft power", has been discussed widely in international relations and is increasingly being used by scholars interested in sport and sport diplomacy (Finlay and Xin, 2010; Mangan, 
2012; Manzenreiter, 2010; Courmont 2013; authors, 2013; Brannagan and Guilianotti, 2014). Simply put, soft power is - for Joseph Nye, who coined it in 1990 - what states ought to seek to use given the changing nature of international relations after the end of the Cold War, and the risk attached to deploying traditional military forms of power (traditionally termed oft power is t Such soft power is made up of 'intangible power resources such as culture, ideology, and institutions' and is clearly becoming more important in inter-state relations (Nye, 1990, 167). We have discussed the concept at length elsewhere (authors, 2013; 2014; 2015) so will only offer a cursory introduction here. Nye distinguishes between the power to sources such as culture, ideology, and institutions' and is clearly becoming more important in inter-state relations (Nye, 1990, 167). We have discussed the concept at length elsewhere (authors, 2013; 2014; 2015) so will only offer a cursory introduction here. Nye distinguishes between the power to 'influence the behavior of others to get the outcomes one wants' (coercive power) and the ability to 'attract and co-opt them to want what you want' (soft power) $(2004,2)$. As authors $(2013,6)$ suggest:

...the ideational dimension to soft power is key and is found in the ability of states to communicate universally shared values (such as, we argue, those rooted in international sporting competition) in order to court the publics of other states. Used in this way, soft power is a discursive mechanism for increased agency in global affairs through the performative politics of attraction rather than the use (or threat of use) of military or economic force. In this sense soft power resides in the ability to shape the preferences of others and align those preferences to your own.

Interestingly for the current discussion is the fact that it was Nye who recently suggested that the Russian President Putin "failed to capitalize on the soft-power boost afforded to Russia by hosting the 2014 Winter Olympic Games in Sochi” (Nye, 2014). With the political volatility in the region throughout the year, Russia's ensuing actions culminating in the secession of Crimea - and its position over the armed conflict in Ukraine, certainly appear to bear this out. This article sets out why Nye and others are mistaken in their assessment of Russia's soft power strategy. The simple answer, as we show, is that viewing and framing the Sochi Olympics as a Russian attempt to obtain belated recognition as a great power is to misunderstand the Games and their meaning for 
Russia. This chimes with the popular view that elite sport and mega-events in particular, perpetuate and legitimatize Western civilisational standards and could be viewed as a variation of 'soft cultural colonisation'. As Horton and Saunders put it, "the founding of the International Olympic Committee (IOC) in 1894 could be said to represent the formal institutionalisation of the Western imperialist model of sport and its associated discourse which, largely, still holds sway today" $(2011,890)$.

Therefore seen thus, emerging states, including the BRICS countries, attempting to wield soft power through hosting the Olympic Games only stand a chance of success to the extent that their modernities are consistent with a neo-liberal paradigm of development. This is, first of all, due to the fact, that irrespective of the hosts' best effort, a critical Western media framing often prevails, unearthing all the deficiencies of the hosts' political system and social order, epitomized in the event preparation process (Manzenreiter, 2010). With a mega-event serving as a magnifying glass, highlighting cultural positive but also unwelcome truths, developing countries often fail to receive universal acclaim for their alternative modernities (Horton and Saunders, 2011; Mangan, 2012). On the other hand, it raises a question about the tenacity of the hegemonic worldview of the Western media, which self-righteously passes an exclusive sentence without due regard for other possible audiences (Finlay and Xin, 2010). The argument is that the emerging states' soft power projects may be more selective, primarily directed at other states with comparable political economies and levels of development, or at states within their region (rather than being designed to embrace the world at large). Brazil is a case in point, as it sets out to secure its position as the leading regional actor in Latin America as well as becoming a global actor (authors, 2014). In this respect, and taking into account the global reach of the messages transmitted via sports mega-events, the international objective of developing nations may be twofold: to appeal to the one group of states, thereby wielding soft power (authors, 2013), while emphatically and assertively informing the others of their intentions. Russia's great power claims, for example, persisting for some time and gaining currency during the Olympics, with little universal attraction potential to them, were rather intended to inform the West of its coveted place in the global political hierarchy. On the other hand, there is a growing reckoning that Western understanding of liberalism and democracy is unlikely to find traction in some nation-states and that Russia is not only one such state, but it is also a 'resister state' (Lankina and Niemczyk, 2014) with its own distinctive and (potentially) endearing values and leadership style, if not institutions (Pu and Sweller 2014). 
Great powers, or in Russia's case, an aspiring great power, traditionally prioritized domestic audiences through such ambitious projects rather than specifically "signalling" to foreign publics. As Pu and Sweller state $(2014,145)$ :

"For rapidly ascending states, in particular, the domestic audience usually trumps the international one [...] Because the continued rise of emerging powers is rarely a given, the process of rapid development usually generates generous social and political dislocations, and future growth and internal stability often require fundamental political reforms.

It could be argued, therefore, that the Sochi Olympics were designed above all as a source of domestic soft power rather than simply an external "signalling" exercise. Such a strategy is not dissimilar to Beijing which also pursued a politics of "two level games" (Putnam, 1988). Putnam's phrase refers to the intertwined nature of both international and domestic politics and leads to a more nuanced understanding of soft power rather than seeing it simply as an instrumental status marker in the same vein as, for example, attempting to gain "membership in elite clubs, such as the Group of 8 (G8), permanent membership in the UNSC, [and] leadership positions in international organizations" (Welch et al. 2014,10).

It could, therefore, be further suggested that the main objective of the Russian soft power project is to instigate a sense of self-worth, patriotism and to cultivate a viable national idea (see Courmont, 2013, for parallels with China). While sport has always been a major tool of "collective identification" (Jackson and Haigh, 2008), providing a strong impetus for national identity construction and stimulating ardent nationalistic sentiments, it has been cunningly used by regimes in the past to strengthen the national idea and even infuse it with a new vigour on the eve of conflict. The war-like rhetoric prevalent in the framing of the Sochi Olympics in Russia (Sperling, 2003). Thus, the Sochi Olympics were promoted by the Putin government, and this view was eagerly embraced by a large section of the population, as an ongoing war between the West and Russia, which was only strengthened by the belligerent media framing assumed in the West. As a result, the 2014 Winter Olympics served a double purpose, entrusted to them by the ruling elite, to ignite a patriotic sentiment and to be perceived as a unifying cultural symbol, compared to World War II in the 20th century, laying the ground for the emergence of the potent new Russian myth (Persson \& Petersson, 2014). Such historical 
rhetoric prevalent in the framing of the Sochi Olympics that relate collectively shared moments of the development of a nation (authors, 2015). In this respect, Makarychev and Yatsyk (2014) also draw parallels between the Sochi 2014 Games and the annexation of Crimea based on their contribution to what is considered by Putin to be a great power status. These two events served as a force of "domestic consolidation" behind Putin's aims and a trigger for domestic soft power; that is, the attempt to influence a domestic audience by providing them with a growing sense of Russian national narrative.

Mass opinion polls conducted in Russia in 2014-2014 can be eloquent illustrations of this trend. According to the Russian news agency Novosti, the post-Sochi period led to the unprecedented popularity of Putin at home, with him polling an all-time high of 85,9 per cent in May 2014. In 2015 around 46 per cent of respondents believe that the Sochi Olympics led to the improvement of Russia's international prestige, with 36 per cent convinced of its positive role in the rise of patriotic sentiment (WCIOM 2015).

\section{The Sochi Olympics and an Alternative Interpretation of Soft Power}

Rather than understanding Sochi as a stepping-stone en route to 'emerging' as a power, Russia viewed the Olympics first and foremost as a belated recognition of its equitable status or 'growing agency' in the global order (Muller, 2014) or as Putin more diplomatically put it 'an assessment of our country' (Alekseyeva, 2014). According to the majority of scholars (Persson \& Petersson, 2014; Orttung \& Zhemukhov, 2013), the primary objective of the ruling elite was to validate Russia's claims for the reestablishment of national greatness and underscore the continuity of its indispensability in world affairs through the hosting of the Winter Olympics 2014. Alekseyeva has labelled the Games 'Putin's government's brand of modernisation' (p.160). This argument is substantiated by other grand projects throughout the country, such as the reconstruction of Vladivostok for the Asia Pacific Economic Cooperation Summit (\$20bn), Universiade Games 2013 in Kazan ( $\$ 6.9 \mathrm{bn})$, Skolkovo innovation centre $(\$ 15.2 \mathrm{bn})$, with an imagebuilding apex in shape of the 2018 FIFA World Cup (Alekseyeva, 2014). Golubchikov (2015) rightly points to Sochi as simply a part of a much wider strategy of 'spatial governance' and warns against 'reductionist' accounts of the use of this SME as a signal of Russia's growing power (to an international and domestic audience). He goes on to suggest that the Russian 'government's key rationales with regard to the regional and urban development are conspicuously underplayed' $(2015,2)$. This latter point is significant, because it means that Sochi cannot be understood in isolation, as the massive 
regional and urban re-development projects throughout Russia provide the context in which the Olympics were built and took place.

Such a modernisation programme is not without its problems. For example, it is a rather piecemeal process which takes place in fits and starts, largely at the expense of other more urgent socially-oriented projects and accompanied by omnipresent corruption. Orttung and Zheuchov (2013) went as far as to pigeonhole mega-events as an emblematic feature of Russia's political economy, which officially justifies and almost legalises embezzlement and money laundering. Yet as long as the results are internationally visible and conspicuous enough the government considers the symbolic target to have been reached with no major deviations from their plan (Tsygankov, 2006).

Rebuffing criticism of the Sochi Olympic Games being a piecemeal, money laundering affair, Russian sources emphasize the long term strategic interest in the region and refer to the multibillion dollar investments in both eco-cultural and infrastructural revival of the region. As Kosachev (2014) puts it:

Sochi is not 'Khalif an hour' but a serious long term investment, which has potential after the Olympics.

Investments into sustainable eco-development and restoration of the damaged eco system ( $\$ 95 \mathrm{mn})$, construction of sewage systems and waste recycle plants $(\$ 300 \mathrm{mn})$, and development of energy generation system $(\$ 1,75 \mathrm{bn})$ are among current ambitious postOlympic projects (gorchakovfund.ru) ${ }^{1}$. This ties in with Golubchikov's point above about Sochi being a part of a wider strategic urban and regional development project.

Currently, the success of the Olympic project is exemplified by the inflow of tourists to Sochi in the first post-Olympic summer, totaling 85 per cent of the hotel capacity. This, however, may be attributed not so much to the marketing success of the city as to the international sanctions, depreciating currency and, thus, limited capacity of the population to travel abroad. Some studies (Sakwa, 2011) have also drawn attention to

\footnotetext{
1 'Anton Bredichin: Post Olimpijskij Sochi- Novue Gorizontu Razvitija' [Anton Bredichin: Post-Olympic Sochi - New Horizons of Development], Gorchakov Fund, 16 December 2014, http://gorchakovfund.ru/news/13375/ .
} 
the decisive elements of continuity between 'Putinism' and the political and ideological the political and ideological tradition of the Soviet Union, epitomised among other things by mega-projects, where neither money, nor any other rational considerations except national pride and awe-inspiring gigantism were ever taken into account. There are two established traditional approaches to framing of the Olympic Games hosted by the nonWestern peripheral states. The Olympics are either characterised as a 'coming-out party' of an emerging state and appraised in terms of a 'graduation into the community of civilised nations' (Seoul 1988, Mexico City 1968; Black, 2004; Cho and Bairner, 2011; Mangan, 2012), or assessed as the final rehabilitation benchmark of 'nations that have done their penance for breaking away from the norms shared by core states' (Munich 1972, Tokyo 1964; Finlay and Xin, 2010, p.879; Tagsold, 2010; Kietlinski, 2011).

While democratic nation-states with troubled pasts appear to use SMEs to dissociate themselves from their histories (Germany, Japan, Italy), non-liberal states with communist legacies in particular are comfortable with alluding to what they want to see as nation-defining, though contested, historical periods, often with nostalgic sentiment (for example, China and Russia) (Persson and Petersson, 2014). In this respect, in a 'rehabilitated' state a definitive de-monumentalisation process takes place (Schrag, 2009), evident both in the emerging architectural tradition and in the placatory presentation of its culture, with a tendency to omit, wherever possible, mentioning or detailed elaboration of some historic periods or diminish their significance within national identity. Non-liberal states, on the contrary, appear to increasingly draw inspiration from a menacing and overbearing interpretation of their historic and cultural paths, emblematic in grandiose mega-events designated architecture, meant to invoke 'glory and power'.

Orttung and Zhemukhov (2013) compare the rationale behind the Sochi Olympics to those of the Tokyo Games in 1964, which marked the return of Japan to the world stage and which were perceived as an official declaration of its rehabilitation and acceptance into the international community after World War II. This comparison is highly misleading, though, due to the presence of more apparent differences than similarities between these two cases. The Sochi Olympics were the first global Russian coming out party after the disintegration of the Soviet Union and, consequently, a symbolic defeat in the Cold War. An event, indeed, comparable in significance for 
Russian self-identification to the 1964 Tokyo and 1972 Munich Olympics for Japan and Germany respectively, marking a return of former axis powers to the group of civilized nations. Russia's reception, however, was not a repetition of Tokyo's open-armed welcome back in 1964. Two things were decidedly different: first, Japan was endorsed by the USA at the time in return for a full-hearted acceptance of democratic values and a repudiation of revisionist sentiments. Russia, on the other hand, decided to conspicuously 're-emerge' on its own terms. While Japan badly longed for recognition, Russia appears intent to reaffirm its international standing and receive acknowledgment of legitimacy of its newer-relinquished geopolitical and civilizational ambitions (Tsygankov, 2009; Welch et al, 2010). Japan openly sided with the USA and remains its loyal ally to this day (Lam, 2007); however, making long-term friends does not seem to be among Russia's chief aims, although its omnipresent soft-power rhetoric might give an impression to a casual observer of the obvious adherence to the politics of attraction (Tsygankov, 2006; Laruelle, 2012). The Tokyo Games were largely a USA project, inasmuch as they were thoroughly overseen by the USA and should have exemplified the uncontested success of the American model. In fact, they turned out to be one of the crucial affirmation of American preponderance as 'a society worthy of admiration and deserving emulation' (Brzezinski, 1998, p.8)

Russia's ruthless image-building crusade, on the contrary, only makes it appear a wolf in sheep's clothing, or a burly Siberian bear, intimidating the West and resurrecting its most mortal unconscious fears, which date back to the days of the Cold War or even further back in time (Suslov, 2012; Sakwa, 2011). Deservedly so, because for Russia attractiveness has never meant being unassuming, forthcoming, cooperative or responsive to outer pressures. It has rather been equated with military potential, territorial superiority, technological advancement and dominance of its culture and language (Sperling, 2003), which is more reminiscent of hard power. Modern realities, however, challenge Russia to follow global trends to stay relevant and competitive, subscribing to soft power values seems to be one of them, and thus the prioritisation of mega-events which is part and parcel of soft power strategies, could not better conceal Russian true sentiments. Therefore, an assertion that through hosting the Winter Olympics 2014 Russia was not seeking to demonstrate a certain ideology is only partially true, inasmuch as adherence to any ideology different to that of the dominant paradigm of neoliberalism, taking into account growing disillusionment with the Washington consensus in some parts of the world (Zhang, 2012), is already a very strong point to be made 
especially when it comes from Russia or China. It might not be entirely clear or eloquently articulated even inside the country, due to the protracted ideological vacuum after the collapse of the Soviet Union (Welch et al, 2010; Suslov, 2012), though, it is obvious that the message that comes through is: 'Russia is back and to be reckoned with'.

\section{International views}

Besides the facts directly connected to the mega-event, the international evaluation of the Sochi Olympics is by and large grounded on previous accounts of all events associated with Russia and its historical precursor - the Soviet Union. Indeed, Russia is not only a formal successor to the Soviet Union, it is also a successor to all pervasive cultural stereotypes of the Soviet era. The international community, stirred up by media framing and liberal governments' wariness and offhand rejection of alternative routes of development, tends to draw from a set of long-engrained primitive stereotypes when forming its attitude to the still enigmatic Russia (Sakwa, 2011, Tsygankov, 2009), discarding official information and visual images as propaganda. Interestingly enough, the futility of the recent Russian soft power endeavour may be traced back to what Brzezinski (1998) considers as one of the major reasons behind the Russian loss of influence in Eurasia and defeat in the Cold War. He sees the causes of Russian miseries in the somewhat alien nature of its cultural tradition to Western Europe and subsequent defiance of its growing cultural pre-eminence rooted in distorted and rather arrogant perception on the part of Western Europeans of Russia's inferiority. Furthermore, Rothman (2011) sees the dissemination of liberal ideas and norms, as well as a lack of acceptance of the Soviet system and defiance of its legitimacy in the West, as the causes of the ultimate demise of the Soviet Union and communism. As a result, a global collective consciousness produces an image which is an amalgam of an official political discourse, clichés and occasional personal experience. The Russian government has evidently failed to trigger any fundamental changes in the dominant international image of the country (Nye, 2014) due to the lack of coordinated effort or coherent uniform message and given the unprecedented cost of the Games (Marten, 2014).

From the very moment the Winter Olympics 2014 were awarded to Russia in Guatemala in 2007 it was viewed by many as a dubious choice; first and foremost, because a historically unstable and recently war-ravaged region was selected as a location

(Persson \& Petersson, 2014). The image of the future Games was further exacerbated by Russia's deteriorating relations with the USA and the EU triggered both by discord over 
Russia's domestic policies, such as treatment of the opposition or civil rights issues (Alekseyeva, 2014), as well as international publics' indignation over war in Georgia in 2008. To top it all, the persecution and suppression of the LGBT community and the unresolved conflict with Circassian diaspora also found traction in the West further tarnishing the Games and dissolving the prospects of any soft power benefits for the country (Muller, 2014). The image of the future Games was further exacerbated by Russia Russiat was viewed by many as a dubious choice; first and foremost, because a historically unstable and recently war-ravaged region was selecten or civil rights issues Scrupulous coverage of the internal discontent severely threatened the official metanarrative behind the Games, which portrayed Russia not only as a country growing conscious of its national strengths and with flagrant geopolitical ambitions, but also as a tolerant, inclusive and multicultural community where people enjoy religious and ethnic freedoms and live in full harmony. Persson (2014), however, maintains that Putin's administration pursued an inherently different strategy; knowing that it will get bad publicity irrespective of its own actions, it strived to promote its counter narrative containing as much positive information as possible. The key to this strategy was to secure visibility and make an official view prevail through making an emphasis on quantity rather than quality of the messages. Still, the prevalence of ambitious statements over actual deeds in addition to the absence of fundamental institutional changes (Rutland, 2012) to the system cannot mask certain insincerity and deliberate hypocrisy of the 'New Russia' soft power narrative, which essentially has failed to win the hearts and minds of the international publics. A different view exists, however, that the 2014 Sochi Games becoming the most politicized sports mega-event in recent history, only testifies to the fact that

the political fracas surrounding them is highlighting how Putin resurrected Russia from the darkest decade after the end of the Cold War and became the principal bete noire of Pax Americana (Chaulia, 2014).

\section{Crimean gambit - a 'diversionary' war or a 'great power' dream come true?}

There is a general incomprehension of the reasons behind the annexation of Crimea in the Western media and among academics in view of the lack of any visible hard gains for Russia. The Crimean gambit, allegedly, turned out to be a smokescreen 
that hid Olympic faults and streamlined triumphant great power rhetoric into a new geopolitical dimension. Instead of potentially taking the wind out of Putin's great power ambitions, the political coup in Ukraine, taking place simultaneously with the Olympics in Russia, as if intentionally timed so, brought Russia a large swath of (historically) strategically coveted land. While this internationally condemned move, further exacerbated by the Kremlin's stance on the Ukrainian issue, resulted in strict economic and political sanctions from the West, thus rendering any soft power in the traditional sense unattainable, it still fulfilled the most important goal on Putin's (domestic) soft power agenda so far - namely it elevated national consciousness to unprecedented levels in post-Soviet history. By doing so the coup consolidated public support for Putin's political persona, once again raising 'demophily', or the unconditional love of the Russian population (Fish, 2014). This 'demophily' marked his rule in the 2000s and visibly weakened by the turn of the decade, not least because of the unquenched corruption and money laundering, ubiquitously plaguing the Sochi 2014 project. Putin's actions may seem clearly pointless, considering how bent he was on promoting Russia as a reliable international partner on security issues, as well as committed to peaceful resolution of conflicts and a guardian of inviolability of post-Cold War international political system. Yet, Fish (2014) sees all Putin's internationally self-discrediting moves as a justified trade-off for his popularity at home, arguing that 'the thrust into Ukraine seems to Putin to be the perfect mystique preserver'.

Putin in 2014-2015, as noted by many commentators, bears little resemblance to the man of the 2000s. Nevertheless, speaking of what defines his values, beliefs, and the character of his decisions and, henceforth, the contours of modern Russian policy, both domestic and foreign, as early as 2008, Evans observed that new Russian reality, albeit successful so far, has become an incarnation of a sole man's worldview. What can help to shed light on an incomprehensible, from the West's perspective, annexation of Crimea, is that Putin's actions have never been 'ad hoc responses to immediate conditions' (p.901), but part of a clear-cut, viable strategic vision, which may be summed up as 'Great Russia'. In order to be viable to a domestic audience, this vision has to be replete with symbolism of successive concrete gestures. Irrespective of substantial repercussions, the Sochi 2014 Olympic Games as well as the Crimean gambit could not fit Putin's plan better. In the eyes of Putin these two events, reinforcing one another, is what both 
represents and lays the ground for 'basic national values and tasks' (Putin, 2003), and thus helps overcome societal and class divisions.

On the one hand, endorsement of insurgents and the annexation of Crimea put an end to the discourse of Russia as a normal great power, unraveling the inconsistency of government policies. On the other hand, it may be argued, that Russia only lived up to its demonized image prevalent in the West. Apparently acting against its own soft power interests, among other things, was largely instigated by the constant neglect of Russian opinions on global strategic issues, such as NATO enlargement, the Transnistria conflict, missile defense development in Europe and global democracy promotion through unconstitutional government changes, to name but a few (Tsygankov, 2014). The same holds for offsetting the Russian energy interests in the Caspian area and rejecting any potential partnerships ${ }^{2}$

What Ickes and Gaddy represent as the 'missing quadrant' was being filled in: a strong but 'bad' Russia, not the weak and good Russia of the 1990s, the weak and bad Russia presented by its critics, or the good and strong Russia extolled by its friends. (Sakwa, 2015)

The unwillingness of Western elites to find common ground and a way for Russian integration, let alone accept its claims for a great power status, logically led to an escalation of existential and security concerns and ensuing assertive neo-revisionist behavior. Ascendancy of neo-revisionism was further bolstered by the so-called color revolutions in Ukraine in 2004 and Georgia in 2003, the core inspirations of which was Russia as an irreconcilable enemy, the core inspirations of which was Russia as an irreconcilable enemy, as an 'irrelevant other' to be dissociated with and broken away from at all costs.

Russian foreign policy after the Sochi Olympics, as it currently is, might for a long time to come invalidate the Western-oriented soft power discourse, or an approach that even remotely resembles Nye's initial concept, even if subject to Russian interpretation. Having been at the crossroads of embracing international engagement or

\footnotetext{
${ }^{2}$ For example, the Nabucco pipeline pulling Kazakhstan and Turkmenistan into the orbit of Western influence (Tsygankov, 2014).
} 
'hegemonic order' or 'veering towards outright revisionism' (Sakwa, 2011, p. 968), Russia seems to have made up its mind in favor of the latter. What this implies for Russian soft power aspirations is that if they are not to give way to unrestrained hard power politics altogether, they are bound to change the vector to the Islamic World, epitomized in the resumption of the Iran-Russian nuclear cooperation, with a radical change in rhetoric respectively:

Russia would once again run the danger of becoming the core of the renewed 'third-world' revisionist front, aligned with some of the Islamic world's critique of Western values, an outcome that the country's Eurocentric elites sought to avoid (Sakwa, 2011, p. 968).

In that way, Russia has always followed what Tsygankov $(2009,351)$ refers to as a sort of alternative soft power project, which is developing both within and outside the legitimatizing language of democracy. The difference between pre-Sochi and post-Sochi soft power discourse will lie in the evolution of the language from the democratic (at least on the surface) to the not so democratic.

There is a view, however, that instead of compensating for a lack of soft power, Russian use of force may indeed unprecedentedly add up to its soft power. What is more, Russia by no means is trying to charm the West anymore and, indeed its neo-revisionist behavior will have further consequences. However, its condemnation 'of the decay of liberal world order, the West's double standards in application of international law, and its ostensibly weakening moral authority' (Lankina and Niemczyk, 2014) certainly expresses the view of a large number of the population globally, and championed by Russia and the charismatic Putin will assert its influence even though it may not be the type of soft power as articulated by Nye. The conflict in Ukraine, as such, is an example of the tensions which arise not because Russian soft power is weak, but because the regions where it is strong are not allowed sufficient self-expression and selfrepresentation.

Even though Putin initially looked for opportunities for closer cooperation with the EU and the USA, it is maintained that it was done not out of a desire for institutional and political integration, but exclusively as a pursuit of national economic interest and political realism, albeit not charged with ideological 'grand designs' (Lavrov, 2007, p.8) 
or 'missionary functions' (Putin, 2007). This would not have been inconsistent, however, with 'realism with a strong dose of ideology' (Caldwell, 2007) that marked Russian foreign diplomacy for centuries. Evans argues that Putin was fully aware of the pitfalls of radical ideology, such as a possibility of a resumption of an ideological struggle with the West, which the head of state believed to be outright disadvantageous for Russia. Evans duly pointed out that the rise and nature of a new Russian ideology, as well as ensuing political moves, depends upon the Kremlin to the same extent as they depend upon the eagerness of its Western counterparts either to engage with Russia on equal terms or continue to treat it as an inferior partner (910). The Sochi Olympics, however, symbolically marked a watershed moment both in world politics and Russian national identity ambitions.

\section{Sports Mega events as Building Blocks for a New Russian National Idea}

Apart from dealing with a number of common challenges every dictatorship encounters on the way to democracy (e.g. economic reforms and transition to pluralism) Russia came across a rather more fundamental problem of a formation of a viable national idea to glue together a multi-ethnic state, reflect and inspire a transformation of consciousness, and light up a vision of a worthwhile collective future (Sperling, 2013; Sakwa, 2011; Tsygankov, 2009). The reason behind the demise of a coherent unifying national idea for millions of Russian citizens lies in their disillusionment with the inflated Communist ideology, which has kept a Soviet Utopia alive for more than seventy years. Although considered by Putin and a large proportion of the multi-ethnic Eurasian population as the greatest geopolitical disaster of the $20^{\text {th }}$ century, the Soviet Union could not evade a humiliating defeat and fragmentation. It is evident that a formulation of a national idea in Russia is yet to take place, something that is holding up the nationbuilding process (Tolz, 1998). An emergent Russian national idea will essentially be rooted in its history, the mentality of its citizens and elite, and will be bound to assume features of the political regimes which have shaped the country over the course of time (Laruelle, 2012; Rutland, 2012). The central feature pertaining to the ideology formation process in the newly established democracies is an equal possibility of swaying into either ethnic exclusionism, of which an inflated sense of patriotism is an example, or towards civic liberalism with corresponding consequences for the country and geostrategic realities (Sperling, 2003). 
The use of military vocabulary in the context of the Olympics demonstrates an interesting paradox. Outwardly, that is to the Western onlooker, Russia wants to appear a benign and responsible, though strong and ambitious, agent in international relations, committed to soft power ideals. Inwardly, that is, to the domestic audience, Russia sends a message which is meant to ignite a certain hostility against an outside world and to juxtapose 'us against them' and thus to use the West as a dissociative group in this identity building enterprise. An attempt to evoke a war-like patriotism is also grounded in the absence of other potent unifying memories apart from victory in World War II, which could arouse pride and be credible to a multi-ethnic, multimillion nation.

The year after the Sochi Olympics Russia was characterised by what Makarychev and Yatsyk $(2015,67)$ see as a 'dominating trend towards an increasingly more pronounced imperial identity and its Anti-Western reverberations'. It did not happen out of the blue, however. As far back as 2007 the concept of 'sovereign democracy' started to feature in official rhetoric as a model with alleged global soft power potential, similar to the Beijing consensus based on economic success and a centralized state, considering that the Western liberal democracy is imperfect and not universally applicable (Polyakov, 2007; Evans, 2008). Undoubtedly, any sort of Russian soft power promotion or such concrete projects as sports mega-events would have been impossible without the presence 'of a relatively coherent, emotionally charged, and conceptually interlocking, set of ideas' (Hunt, 1987, p.15), which constitute an ideology. The ideology of contemporary Russia dates back to the coining of the notion of 'sovereign democracy' by Vladislav Surkov in 2006.

This concept as such implies that instead of mechanically copying other countries 'experiences' (Putin, 2007) there is an inalienable right of a nation-state to define not only their contours and foreign policy, but also to independently establish the foundations of its own national identity (Putin, 2005) and henceforth envisaged future. In this respect, the Sochi Olympics were expected to provide the Russian people with a future-looking national symbol. They were to become a point of reference for a new Putin-ruled generation of people, a reinvigorating milestone for the new glorious national identity. Although born out of the heroics of the WWII, space explorations, world-class culture and cutting-edge science, this identity depreciated in the turmoil of the 1990s and has little relevance for the youth of the 21 st century. In this respect, sports mega-events are to deal with the pervasive habit of historical self-referencing. In more pragmatic terms, 
'Putinism' as an ideology is based on a negation of the 1990s, while continuing its fundamental projects: 'marketisation, democratization, and international integration' (Sakwa, 2011, p.961).

Obvious contradictions in this new ideology may be put down to Putin's propensity to accommodate deeply conflicting visions of Russian identity, that is of the Westernisers and Easternisers (Laruelle, 2012; Tsygankov, 2007), the primary concern of which are integration vs national autonomy, democracy vs sovereignty, ideology vs pragmatism. Not logically justified from the West's perspective, the Kremlin's policy towards Ukraine is, nevertherless, in perfect compliance with domestic civilisational discourse, in particular with the Expansionists view that Russia 'is powerful enough to deploy its soft power coercively and without regard for the ex-republics desire to develop relationships with the European Union and the United States' (Tsygankov, 2009, p.356).

This paradigmatic dichotomy, in addition to exogenous factors, is identified by Sakwa (2011) as a stumbling block on Russia's road to a fully-fledged international integration and what precludes it from occupying an acceptable place in the hierarchy of nations. He, therefore, assigns a central role to establishing a compromise between an international integration and a strong state with a new symbiotic national identity.

\section{Conclusion}

In this piece we argued that the Kremlin forefronted the domestic over the international dimension in its SME soft power strategy. The vast majority of SME soft power strategies are outward looking and intended to help the host 'emerge' in terms of economic and political development. Russia did not use the SME in the same manner as most other states, emerging or otherwise. Instead, the Sochi Olympic Games and subsequent annexation of Crimea, while exemplifying the application of both soft and hard power respectively (Nye's so-called 'smart power'), were an attempt to lend a forward-looking dimension to a traditionally backward-looking, nostalgic Soviet-era and imperialist-rooted national identity discourse. It seems the domestic soft power project has succeeded so far, given the improvement of Putin's approval ratings from 54 per cent in 2013 (Ray, 2014), to 75 per cent just after the Olympics (RT.com) and an extraordinary 86 per cent in February 2015 (Saeed, 2015). Equally, Sochi ought to be understood as part of a wider strategy of urban regeneration and restructuring. The vast 
majority of SME soft power strategies are outward looking and intended to help the host boost their international prestige. The Russian case appears different with an emphasis on a domestic audience. There also appears to be signs of the mobilization of a Russian national consciousness and self-identification. It remains to be seen whether the arising ideology becomes a resuscitating inspiration for the nation or a spiritual straightjacket or developmental trap. As for the international aspect, Joseph Nye (2014) made it clear that not only did Russia fail to capitalize on the Sochi Olympics as a source of soft power, its ultimate interpretation of the concept has little to do with what he initially envisaged.

As we have attempted to show, such an assessment is too 'Western'; that is, it does not allow for alternative views of Russia's strategy. For example, Lankina and Niemczyk (2014) suggest that the West runs the risk of underestimating the sources and reach of Russian attractiveness to others. Russian soft power is not meant for people not already sharing ethnic or cultural ties with Russia. That is, it is neither expansionist nor an aggressive imperialist idea, bent on subduing cultures and communities in order to integrate them into multifaceted Russian civilization, nor is it a cosmopolitan evangelism for Soviet people. Moreover, despite a visible blow the Russian economy suffered as a result of sanctions and a depreciating currency, it still remains the most influential among the post-Soviet states, being thus far indispensable for its neighbours.

While some argue that Putin's decisions will be fatal for his authoritarian neorevisionist system in the long run, there is a growing understanding that Putin's actions could have been defensive rather than offensive (Sakwa, 2015; Tsygankov, 2014). It is the so called 'war to stop NATO enlargement' - an issue that has been the most inflammatory bone of contention between Moscow and Washington ever since the dissolution of the Soviet Union. Continuously ignoring the Kremlin's pleas to stop the block's advancement, Russia believes that the West had its way, thus legitimately raising the Kremlin's security concerns and testing Putin's temper to its limits. Therefore, prognoses of Putin's system's imminent dissolution may be a little hasty without an indepth understanding of the peculiarities and dynamics of Russian public thought, which historically defy analogy with any Western case. One thing is clear for now: the conflict in Ukraine challenges the essence and sustainability of the Kremlin's international soft power proposition, and its recovery would require strategic actions. The outcome of the Ukrainian affair, which became a fully-fledged civilizational contest between Atlantisim 
and Eurasianism, liberal democracy and authoritarianism, will largely define Russian soft power and great power ambitions and prospects for a long time to come.

\section{References}

WCIOM. 2015. "Sochi Olympics: A Year After". Russian Public Opinion Research

Center, 5 February 2015. http://www.wciom.com/index.php?id=61\&uid=1069.

Alekseyeva, A. 2014. "Sochi 2014 and the rhetoric of a new Russia: image construction through mega-events". East European Politics 30(2): 158-174.

Almeida, B.S., Marchi, W. J., and E. Pike. 2013. "The 2016 Olympic and Paralympic Games and Brazil's soft power". Contemporary Social Science 9(April 2015): 271-283.

Authors, $(2013 ; 2014 ; 2015)$.

Baviskar, A. 2014. "Dreaming Big: Spectacular Events and the 'World-Class' City: The Commonwealth Games in Delhi", in Leveraging Legacies from Sports MegaEvents: Concepts and Cases, edited by J. Grix. Basingstoke: Palgrave.

Black, D. 2008 "Dreaming big: the pursuit of "second order" games as a strategic response to globalization", Sport in Society 11( 4): 467-480.

Black, D. and Van der Westhuizen, J. 2004. "The Allure of Global Games for "Semiperipheral' Polities and Spaces: A Research Agenda", Third World Quarterly, 25(7): 1195-1214.

Brannagan, P. M., and R. Giulianotti. 2014. "Soft power and soft disempowerment: Qatar, global sport and football's 2022 World Cup finals. Leisure Studies (April 2015): 1-17.

Brzezinski, Z. 1998. The Grand Chessboard. New York, Basic Books.

Caldwell, L. T. 2007. "Russian Conception of National Security", in Russian Foreign Policy and the Shadow of the Past. New York, Columbia University Press, edited by R. Levgold, 279-342. New York, Columbia University Press.

Chaulia, S. 2014. "Putin's Pride, West's Spite". The Statesman, October 9. http://www.thestatesman.com/news/38535-Special-Item.html.

Cho, J. and A. Bairner. 2011. "The sociocultural legacy of the 1988 Seoul Olympic Games". Leisure Studies 31( 3): 271-289.

Courmont, B. 2013. "What Implications for Chinese Soft Power: Charm Offensive or New Hegemony?” Pacific Focus 28(3): 343-364.

Evans, A. B. 2008. "Putin's Legacy and Russia's Identity”. Europe-Asia Studies 60(6): 899-912.

Finlay, C. J., and X. Xin. 2010. "Public diplomacy games: a comparative study of American and Japanese responses to the interplay of nationalism, ideology and Chinese soft power strategies around the 2008 Beijing Olympics". Sport in Society 13(5): 876-900. 
Fish, S. 2014. "The end of the Putin mystique". Washington Post, April 3. http://www.washingtonpost.com/blogs/monkey-cage/wp/2014/04/03/the-end-ofthe-putin-mystique/.

Giulianotti, R. 2015. "The Beijing 2008 Olympics: Examining the Interrelations of China, Globalization, and Soft Power". European Review 23: 286-296.

Golubchikov, O. 2015. From a sports mega-event to a spatial mega-project: rehearsing therationale and legacies behind the 2014 Sochi Winter Olympics. Paper presented at the Leverhulme Project workshop (State Leveraging Strategies and SMEs), Sao Paulo, September 3.

Horne, J. and W. Manzenreiter (eds.) 2006. Sports Mega-Events: Social Scientific Analyses of a Global Phenomenon. Oxford: Blackwell.

Horton, P., and J. Saunders, 2012. "The 'East Asian' Olympic Games: what of sustainable legacies?" The International Journal of the History of Sport 29(April 2015): 887-911.

Hunt, M. 1987. Ideology and US Foreign Policy. New Haven, Yale University Press.

Jackson, S. J., and S. Haigh. 2008. "Between and beyond politics: Sport and foreign policy in a globalizing world". Sport in Society 11(4): 349-358.

Kietlinski, R. 2011. "One world one dream? Twenty-first century Japanese perspectives onhosting the Olympic Games". Sport in Society 14(February 2015): 454-465.

Kosachev, K. (2014). "Tri Prichinu Deformazii Imidja Rossii na Zapade". Gorchakov Fund, June 10. http://gorchakovfund.ru/news/11676.

Lam, P. E. 2007. "Japan's Quest for "Soft Power": Attraction and Limitation. East Asia 24(4): 349-363.

Lankina, T., and K. Niemczyk. 2014. "What Putin gets about soft power". Washington Post, April 15. http://www.washingtonpost.com/blogs/monkeycage/wp/2014/04/15/what-putin-gets-about-soft-power/.

Laruelle, M. 2012. "Larger, Higher, Farther North ... Geographical Metanarratives of the Nation in Russia". Eurasian Geography and Economics 53(5): 557-574.

Lavrov, S. 2007 “Sderzhivanie Rossii: nazad v budushchee?". Rossiya v globalbal politike, 4. http://www.globalaffairs.ru/number/n_9236.

Makarychev, A., and A. Yatsyk. 2014. "The Four Pillars of RussiaA. budushchee?ey-c". The International Spectator 49: 62-75.

Mangan, J. A. (2012). "Soft Power Politics, Hegemonic Realities and Eastern Promise: Changing Circumstances - 'Look East Young Man and Woman'!" The International Journal of the History of Sport 29 ( 17): 2355-2359.

Manzenreiter, W. 2010. "The Beijing Games in the Western Imagination of China: The Weak Power of Soft Power". Journal of Sport \& Social Issues 34(1): 29-48.

Marten, K. 2014. “Crimea: Putinort \& Social Issues ”. Washington Post, March 26. http://www.washingtonpost.com/blogs/monkey-cage/wp/2014/03/26/crimeaputins-olympic-diversion/.

Müller, M. 2014. "Introduction: Winter Olympics Sochi 2014: what is at stake?" East European Politics 30(2): 153-157. 
Nye, J. 2014. "Putin's Rules of Attraction". ProjectSyndicate, December 12. http://www.project-syndicate.org/commentary/putin-soft-power-declining-byjoseph-s--nye-2014-12.

Orttung, R. W., and S. Zhemukhov. 2014. "The 2014 Sochi Olympic mega-project and Russia's political economy”. East European Politics 30(2): 175-191.

Persson, E., and B. Petersson. 2014. "Political mythmaking and the 2014 Winter Olympics in Sochi: Olympism and the Russian great power myth". East European Politics 30(2), 192-209.

Petersson, B. 2001. National Self-Images and Regional Identities in Russia. Ashgate: Aldershot.

Petersson, B. 2013. "The Eternal Great Power Meets the Recurring Times of Troubles: Twin Political Myths in Contemporary Russian Politics." European Studies: A Journal of European Culture, History and Politics, European Cultural Memory Post-89 30: 301-326.

Petrone, L. 2011. "Institutionalizing Pluralism in Russia: A New Authoritarianism?" Journal of Communist Studies and Transition Politics 27(2): 166-194.

Polyakov, L. 2007. "'Suverennaya demokratiya: politicheskii fakt kak teoreticheskii predmetnost", Obshchestvennye nauki i sovremennost, 2:59-68.

$\mathrm{Pu}, \mathrm{X}$. \& Sweller, R. L. 2014. 'Status Signaling, Multiple Audiences, and China's BlueWater Ambition", in Status in World Politics, 141-162, edited by T.V. Paul. New York, Cambridge University Press.

Putin, V. 2003, "Poslanie Federal'nomu Sobraniyu Rossiiskoi Federatsii”, May 16, presidential website, available at: http://www.kremlin.ru/mainpage/shtml.

Putin, V. 2005 “Interv'yu 'Radio Slovenksogo' i Slovatskoi telekompanii STV”, Presidential website, 22 February. http://www.kremlin.ru/mainpage/shtml.

Putin, V. 2007 "Vstrecha s uchastnikami mezhdunarodnogo diskussionogo kluba $\begin{array}{llll}\text { Valdai", } & \text { Presidential } & \text { website, } & \text { September }\end{array}$ http://www.kremlin.ru/mainpage/shtml.

Ray, J. 2014. "Putin's Popularity Waned at Home Before Olympics". Gallup Portal, February 13. http://www.gallup.com/poll/167408/putin-popularity-waned-homeolympics.aspx.

Rothman, S. B. 2011. "Revising the soft power concept: what are the means and mechanisms of soft power?" Journal of Political Power 4(1): 49-64.

RT. 2015. "Putin's trust rating hits 85\% historical high". RT Channel, February 13. http://rt.com/politics/232115-putin-trust-rating-maximum/.

Rutland, P. 2012. "Still out in the cold? Russia's place in a globalizing world". Communist and Post-Communist Studies 45(3-4): 343-354.

Saeed, A. 2015. Vladimir Putin's approval rating? Now at a whopping $86 \%$. CNN Channel, February 26. http://edition.cnn.com/2015/02/26/europe/vladimir-putinpopularity/.

Sakwa, R. 2011. "Russia's Identity: Between the "Domestic" and the "International." Europe-Asia Studies 63(6): 957-975.

Sakwa, R. 2015. Frontline Ukraine: Crisis in the Borderlands. London: I.B.Tauris. 
Schrag, D. 2009. "Flagging the Nation' in International Sport: A Chinese Olympics and a German World Cup". The International Journal of the History of Sport 26 (8): 1084-1104.

Sperling, V. 2003. "The last refuge of a scoundrel: patriotism, militarism and the Russian national idea". Nations and Nationalism 9(2): 235-253.

Suslov, M. 2012. "Geographical Metanarratives in Russia and the European East: Contemporary Pan-Slavism". Eurasian Geography and Economics 53(5): 575595.

Tagsold, C. 2010. "Modernity, space and national representation at the Tokyo Olympics 1964". Urban History 37: 289-300.

Tolz, V. 2010. "Forging the Nation: National Identity and Nation Building in PostCommunist Russia". Europe-Asia Studies 50 (6): 993-1022.

Tsygankov, A. P. 2006. "If not by tanks, then by banks? The role of soft power in Putin's foreign policy". Europe-Asia Studies 58(7): 1079-1099.

Tsygankov, A. P. 2009. "Russia in the Post-Western World: The End of the Normalization Paradigm?" Post-Soviet Affairs 25(4): 347-369.

Tsygankov, A. P. 2014. The Strong State in Russia. Development in Crisis. Oxford University Press.

Welch, D.L., and A. Shevchenko. 2010. "Status seekers: Chinese and Russian responses to U.S primacy". International Security 34 (4): 63-95.

Welch, D.L., Paul, T.V., and W.C. Wohlforth. (2014). "Status and World Order", in Status in World Politics, 3-29, edited by T.V. Paul. New York: Cambridge University Press.

Zhang, W. 2012. "Has Beijing Started to Bare Its Teeth? China's Tapping of Soft Power Revisited”. Asian Perspective 36(4): 615-639. 